\title{
Selective Lesioning of Nuclear Factor-kB Activated Cells in the Nucleus Accumbens Shell Attenuates Alcohol Place Preference
}

\author{
SE Nennig', HD Fulenwider', SH Chimberoff', BM Smith', JE Eskew', MK Sequeira', C Karlsson², C Liang ${ }^{3}$, \\ JF Chen ${ }^{4}, M$ Heilig $^{2}$ and JR Schank*,I \\ 'Department of Physiology and Pharmacology, College of Veterinary Medicine, University of Georgia, Athens, GA, USA; ${ }^{2}$ Center for Social and \\ Affective Neuroscience, Linkoping University, Linkoping, Sweden; ${ }^{3}$ Department of Genetics, University of Georgia, Athens, GA, USA; ${ }^{4}$ Center for \\ Craniofacial Molecular Biology, University of Southern California, Los Angeles, CA, USA
}

\begin{abstract}
Nuclear factor $\kappa$-light chain enhancer of activated B cells (NF-kB) is a transcription factor commonly associated with innate immunity and is activated by infection and inflammation. NF- $\mathrm{kB}$ has recently gained attention as a mediator of complex psychiatric phenomena such as stress and addiction. In regards to alcohol, most research on NF-KB has focused on neurotoxicity and few studies have explored the role of NF-kB in alcohol reward, reinforcement, or consumption. In these studies, we used conditioned place preference to assess the activity of $N F-\kappa B$ in response to rewarding doses of alcohol. To measure NF- $\kappa B$ activity we used a line of transgenic mice that express the Lac $Z$ gene

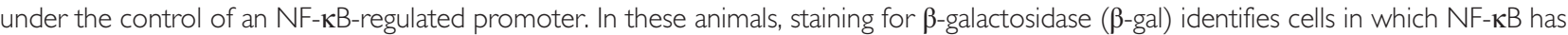
been activated. We then used the DaunO2 inactivation method to specifically silence NF- $\mathrm{KB}$-expressing cells during place preference conditioning. Daun02 is an inactive prodrug that is converted to the inhibitory molecule daunorubicin by $\beta$-gal. After alcohol place conditioning, we observed increased $\beta$-gal staining in the nucleus accumbens (NAC) shell and dorsal raphe nucleus, and found that disruption of NF-kB-expressing cells using Daun02 attenuated the development of alcohol place preference when infused into the NAC shell following conditioning sessions. We found this effect to be regionally and temporally specific. These results suggest that, in addition to its role in alcohol-induced neurotoxicity, NF- $\mathrm{KB}$ mediates the development of alcohol place preference via its actions in the NAC shell. Neuropsychopharmacology (2018) 43, I032-1040; doi:I0.1038/npp.20 I7.214; published online II October 2017
\end{abstract}

\section{INTRODUCTION}

Recently, the impact of the neuroimmune system in behavioral and neurophysiological responses to alcohol has gained much attention (Crews et al, 2015). For example, the transcription factor nuclear factor $\kappa$-light chain enhancer of activated $\mathrm{B}$ cells $(\mathrm{NF}-\kappa \mathrm{B})$, best known for orchestrating the neuroimmune response (Oeckinghaus and Ghosh, 2009), is activated by alcohol administration. Specifically, prolonged exposure to alcohol increases NF- $\kappa$ B DNA-binding levels in conjunction with elevated cytokine expression (Qin et al, 2008; Zou and Crews, 2010). However, the majority of preclinical research on NF- $\kappa \mathrm{B}$ has examined its role in neurotoxicity (Zou and Crews, 2006; Zou and Crews, 2005), particularly when induced by high concentrations of alcohol (Crews et al, 2006; Crews and Nixon, 2009; Qin and Crews, 2012; Zou and Crews, 2010). Virtually nothing is known about the effect of moderate concentrations of alcohol on $\mathrm{NF}-\kappa \mathrm{B}$ function and whether NF- $\kappa \mathrm{B}$ activity contributes to the behavioral effects of alcohol at such doses.

* Correspondence: Dr JR Schank, Department of Physiology and Pharmacology, University of Georgia, 50I DW Brooks Drive, Athens, GA 30602, USA, Tel: +706-542-066l, Fax: +706-542-30I5, E-mail: jschank@uga.edu

Received 8 June 2017; revised 18 August 2017; accepted 5 September 2017; accepted article preview online 13 September 2017
Drugs of abuse such as opiates and psychostimulants activate NF- $\kappa \mathrm{B}$ in the brain, influence spine formation in response to chronic drug exposure, and mediate the rewarding properties of these drugs (Russo et al, 2009; Wang et al, 2004; Zhang et al, 2011). These effects are not likely to be due to drug-induced neurotoxicity and some of these effects have been localized to the nucleus accumbens (NAC). The NAC is part of the mesolimbic reward circuit that consists primarily of dopaminergic neurons projecting from the ventral tegmental area to the NAC, which is a major target of drugs of abuse including alcohol (Boileau et al, 2003; Salgado and Kaplitt, 2015). Given the role of NF- $\kappa$ B in reward for these other substances and the ability of alcohol to stimulate NF- $\kappa \mathrm{B}$, we hypothesized that NF- $\kappa \mathrm{B}$ is involved in the rewarding properties of alcohol as well. Along these lines, a few studies have examined the role of NF- $\kappa \mathrm{B}$ in voluntary alcohol intake. For example, administration of lipopolysaccharide, a cell wall component of gram negative bacteria that stimulates an inflammatory response and increases NF- $\kappa \mathrm{B}$ activity (Qin et al, 2007), results in a persistent increase alcohol consumption (Blednov et al, 2011). Conversely, alcohol intake is attenuated by inhibition of IKK, a kinase involved in NF- $\kappa \mathrm{B}$ activation (Gerondakis et al, 2014; Truitt et al, 2016). Taken together, these findings support the notion that NF- $\kappa$ B positively modulates alcohol reward value and leads to increased consumption. 
In these studies, we assess NF- $\kappa \mathrm{B}$ activity using transgenic reporter mice that express $L a c Z$ under the control of an NF$\kappa \mathrm{B}$ regulated promoter. Thus, wherever NF- $\kappa \mathrm{B}$ is stimulated, activity-dependent $\beta$-galactosidase enzyme ( $\beta$-gal) will be expressed, providing a method for visualization of NF- $\kappa \mathrm{B}$ activity (Bhakar et al, 2002). To achieve highly targeted lesioning of cells in which NF- $\kappa \mathrm{B}$ is stimulated, we used the novel Daun02 inactivation method (Cruz et al, 2013). Daun02 functions as an inactive prodrug that is catalytically converted to its active state, daunorubicin, in the presence of $\beta$-gal (Farquhar et al, 2002). Daunorubicin then permanently destroys the $\beta$-gal-expressing cells through apoptotic mechanisms (Pfarr et al, 2015). This method of inactivation has been used in a series of studies by Hope and colleagues using Fos-LacZ transgenic rats to study neuronal ensembles involved in drug-induced behaviors (Bossert et al, 2011; Cruz et al, 2014; de Guglielmo et al, 2016; Fanous et al, 2012; Funk et al, 2016; Koya et al, 2009; Pfarr et al, 2015).

In the present study, we set out to characterize the functional involvement of $\mathrm{NF}-\kappa \mathrm{B}$ within specific brain regions in alcohol conditioned place preference (CPP). In our initial experiments, we found that NF- $\kappa \mathrm{B}$ activity was specifically increased in the NAC shell and dorsal raphe nucleus (DR) after alcohol conditioning, but not following testing for place preference. This fits well with the literature demonstrating a role for $\mathrm{NF}-\kappa \mathrm{B}$ in learning and memory formation (Snow et al, 2014). Therefore, we targeted these regions using the Daun02 method following alcohol conditioning sessions in attempt to disrupt the development of alcohol CPP.

\section{MATERIALS AND METHODS}

\section{Animals}

Male and female NF- $\kappa \mathrm{B}-\mathrm{LacZ}$ mice (Bhakar et al, 2002; Russo et al, 2009) on a C57BL6/J strain background ages 3-6 months were used. Mice were group housed on a normal light cycle (lights on $0700 \mathrm{~h}$ and off $1900 \mathrm{~h}$ ) in the UGA College of Veterinary Medicine vivarium. Testing took place during the light phase. Food and water was available ad libitum. All protocols were approved by Institutional Animal Care and Use Committee of the University of Georgia and experiments were performed in accordance to these guidelines.

\section{Drugs}

Ethanol was diluted to a $20 \% \mathrm{v} / \mathrm{v}$ solution in $0.9 \%$ saline and delivered intraperitoneal at a dose of 2.0 or $1.5 \mathrm{~g} / \mathrm{kg}$ depending on experiment. Volume-matched saline injections were administered to control animals. Daun02 (ApexBio Technology, Houston, TX) was prepared in 20\% DMSO, 5\% Tween $80,75 \% 0.01 \mathrm{M}$ PBS to a final concentration of $3.3 \mu \mathrm{g} / \mu \mathrm{l}$.

\section{Conditioned Place Preference}

CPP was used to assess the rewarding properties of specified doses of alcohol. The two compartment CPP chambers (Med Associates, Fairfax, VT) had one side with white walls/grid flooring, whereas the other side had black walls/bar flooring. CPP chambers were located within a testing suite in the vivarium. Mice were habituated to the testing room for an hour before the start of testing. During pretest, mice were allowed to roam freely in the apparatus for $15 \mathrm{~min}$. The compartment in which the mice were initially placed was random and alternated between the white and black sides. Groups were formed using an unbiased and counterbalanced design. Specifically, half of the animals received alcohol on their preferred side and half on their non-preferred side, and half of the animals received alcohol on the black side and half on the white side. For saline-saline controls, the afternoon conditioning side was balanced in the same way. Conditioning occurred for three consecutive days, with saline injections in the morning and ethanol injections (2 or $1.5 \mathrm{~g} / \mathrm{kg}) 4 \mathrm{~h}$ later. The test session was conducted 1 or 3 days following the third day of conditioning (see experimental timelines) and took place at a time of day halfway between conditioning sessions. During the test, mice were placed into the chambers without pretreatment in a randomized, alternating pattern (black $v s$ white). Mice were allowed to roam the apparatus freely for $15 \mathrm{~min}$. If specified, an additional $15 \mathrm{~min}$ retest was performed. Preference scores were calculated by subtracting the amount of time spent on the saline paired side from the amount of time spent on the alcohol paired side.

\section{Immunohistochemistry}

In these experiments, we used a line of NF- $\kappa \mathrm{B}-L a c Z$ reporter mice, which allows for the visualization of NF- $\kappa \mathrm{B}$ activation via staining for $\beta$-gal. Two hours following the third alcohol $(2.0 \mathrm{~g} / \mathrm{kg})$ conditioning session, mice were overdosed with ketamine/xylazine and were transcardially perfused with $4 \%$ paraformaldehyde. Brains were postfixed overnight in $4 \%$ paraformaldehyde, transferred to $30 \%$ sucrose until the tissue sank, then frozen quickly on powdered dry ice. Thirty micrometer sections were collected in a freezing cryostat (Leica, Buffalo Grove, IL) and floating sections were frozen in cryopreservant at $-20^{\circ} \mathrm{C}$. After washing, tissue was incubated for $48 \mathrm{~h}$ with chicken anti- $\beta$ gal $(1: 1,000$, Abcam, Cambridge, MA) at $4{ }^{\circ} \mathrm{C}$, followed by incubation with biotinylated goat anti-chicken secondary (1:500, Vector Labs, Burlingame, CA), and visualization with $\mathrm{DAB}$ chromagen. Stained sections were then mounted onto glass microscope slides and coverslipped. Images were taken on a Zeiss Axioscope A1 and quantified using ImageJ. For NAC shell, images from six fields (three per side) were taken at $\times 40$ magnification and the average of these fields was used as the dependent measure. For DR, one field was imaged at $\times 20$ magnification and used for quantification. Cell counts were completed by an investigator blind to experimental conditions.

\section{Immunofluorescence}

To assess the activation of NF- $\kappa \mathrm{B}$ in neurons, we co-labeled for $\beta$-gal and the neuronal marker (NeuN) in the NAC shell and DR. After washing, fixed tissue was stained with both chicken anti- $\beta$ gal $(1: 1,000$, Abcam) and rabbit anti-NeuN (1:500, Millipore, Temecula, CA) for $48 \mathrm{~h}$ at $4{ }^{\circ} \mathrm{C}$. Fluorescent secondary antibodies used were goat anti-chicken Alexafluour 488 and goat anti-rabbit Alexafluor 633 (1:500, Life Technologies, Carlsbad, CA). Stained sections were then mounted onto glass microscope slides and coverslipped. Images were taken on a Zeiss $\mathrm{L} 710$ confocal microscope $(\times 40$ 
for NAC and $\times 20$ for $\mathrm{DR}$, as above) and quantified using ImageJ.

\section{Cannula Implantation}

In order to deliver Daun02 intracranially, mice underwent cannulation surgeries. Mice were anesthetized using a mixture of ketamine $(100 \mathrm{mg} / \mathrm{kg})$ and xylazine $(20 \mathrm{mg} / \mathrm{kg})$. Cannulae (Plastics One, Roanoke, VA) cut to $4 \mathrm{~mm}$ in length were stereotaxically implanted (Stoelting, Wood Dale, IL), aimed at coordinates (relative to bregma in flat skull position) for the NAC shell (bilateral, AP: $+1.7 \mathrm{~mm}$, ML: $\pm 2.3 \mathrm{~mm}, \mathrm{DV}$ : $-3.7 \mathrm{~mm} ; 20^{\circ}$ angle) or DR (unilateral, AP: $-4.4 \mathrm{~mm}, \mathrm{ML}: \pm 1.2 \mathrm{~mm}, \mathrm{DV}:-3.0 \mathrm{~mm} ; 22^{\circ}$ angle). Injectors a

\begin{tabular}{|c|c|c|} 
Day 1 & Day 2-4 & Day 5 \\
\hline Pretest & Conditioning & Test
\end{tabular}

C

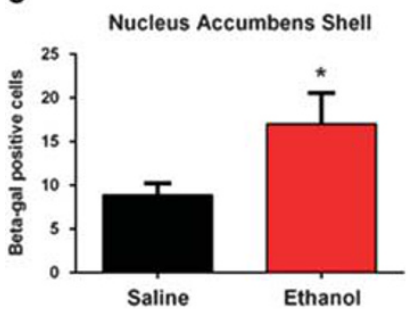

e

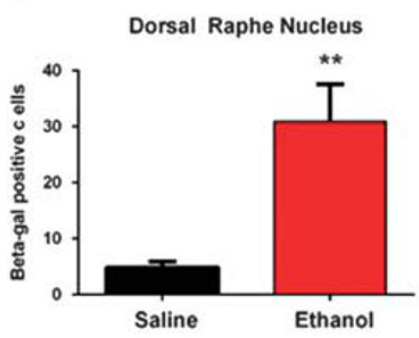

b

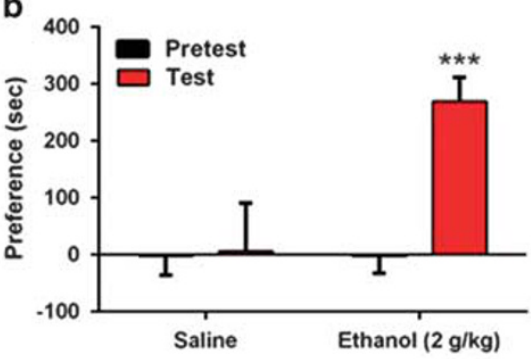

d
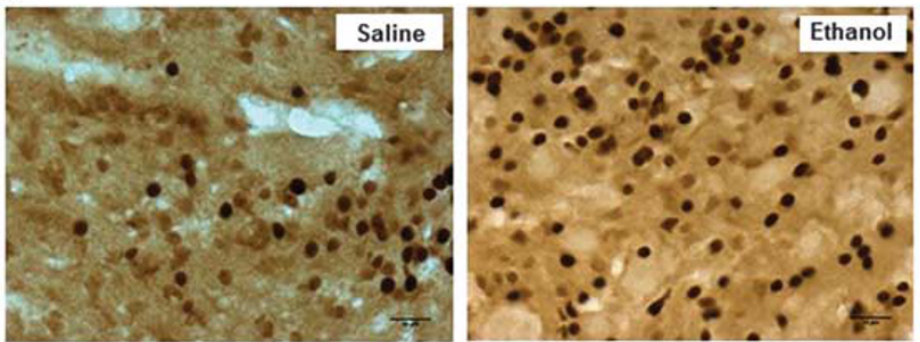

f

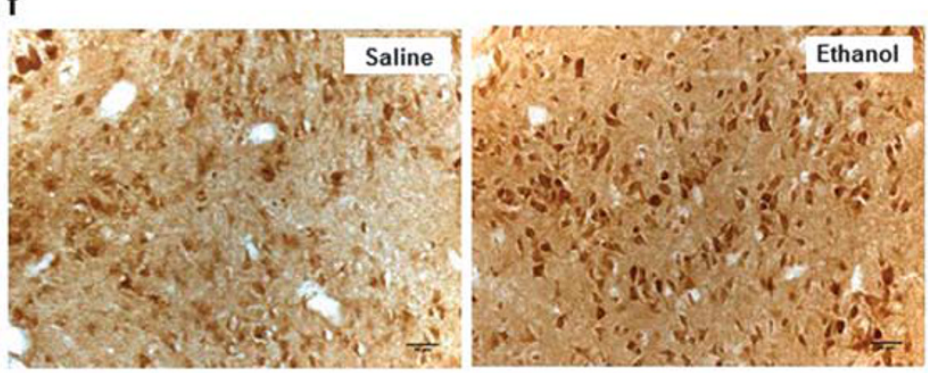

g

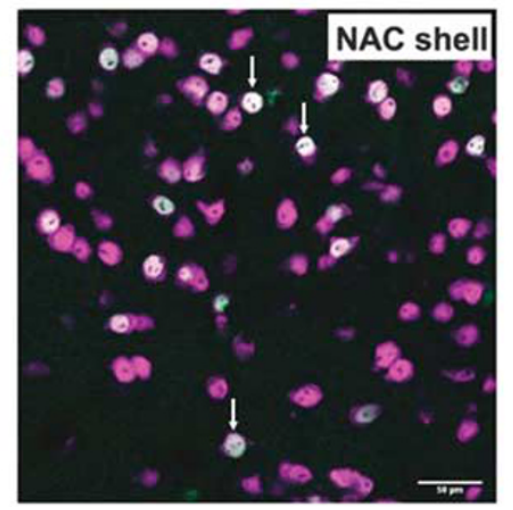

h

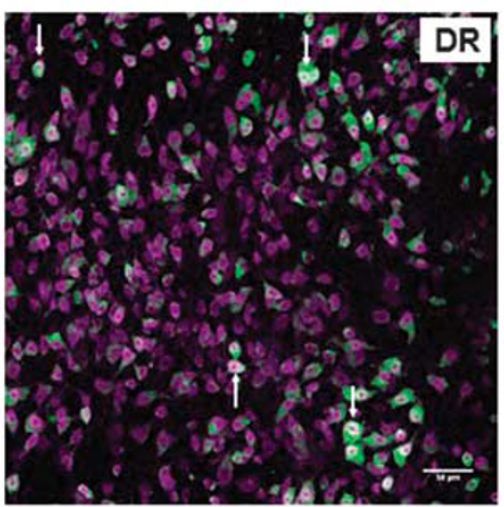

Figure I Nuclear factor $\kappa$-light chain enhancer of activated B cells (NF- $\kappa$ B) is activated by alcohol place conditioning. (a) Timeline of experimental treatments and behavioral measurements. (b) Ethanol $(2 \mathrm{~g} / \mathrm{kg}$ ) induced a strong place preference on test day. No significant change from pretest preference was observed in saline controls. $* * * * 0,0.001$ compared with all other groups. $(c, d)$ Graphical representation and representative images of $\beta$-gal-positive cell counts in nucleus accumbens (NAC) shell following place conditioning. Original magnification $\times 40$. * $p<0.05$ compared with saline group. (e, f) Graphical representation and representative images of $\beta$-gal-positive cell counts in dorsal raphe nucleus (DR) following place conditioning. Original magnification $\times 20$. $* * * 0.01$ compared with saline group. $(g, h)$ Representative images of NeuN (purple) and $\beta$-gal (green) double labeling in the NAC shell ( $\times 40)$ and DR (×20). White arrows indicate representative cells with $\mathrm{NeuN}$ and $\beta$-gal co-localization. Scale bars, $50 \mu \mathrm{m}$. 
were $5 \mathrm{~mm}$ in length and extended $1 \mathrm{~mm}$ past guide cannulae. Coordinates accounted for $1 \mathrm{~mm}$ extension. Dummy caps were inserted to protect the cannulae. Mice were injected with $5 \mathrm{mg} / \mathrm{kg}$ carprofen immediately following surgery and for 2 days thereafter. Mice were allowed 7 days to recover before behavioral testing started. At the completion of each experiment, cresyl violet was delivered via the cannulae and brains were sectioned to ensure proper placement. Animals in the NAC shell experiments were excluded from the study if both cannulae were misplaced. Behavioral data for mice with one or two accurate NAC shell placements were compared statistically and no significant differences were found. Cannula placements are shown in Supplementary Figure S1 (NAC shell) and Supplementary Figure S2 (DR).

\section{Intracranial Infusions}

Injector needles were connected via polyethylene tubing to a $10 \mu \mathrm{l}$ gastight Hamilton syringe (Reno, NV) and secured to a programmable syringe pump (New Era Pump Systems, Farmingdale, NY). For Daun02 experiments, Daun02 $(2 \mu \mathrm{g})$ or vehicle was intracranially infused in a volume of $0.6 \mu \mathrm{l}$ at a rate of $0.5 \mu \mathrm{l} / \mathrm{min}$. Injectors stayed in place $1 \mathrm{~min}$ following the completion of the infusion. Daun02 dose was based on the study by Koya et al (2009), which resulted in selective disruption in fos-LacZ rats. Mice were infused with Daun02 or vehicle $2 \mathrm{~h}$ following each alcohol conditioning session due to our immunohistological results, which indicated a difference in NF- $\kappa \mathrm{B}$ activation $2 \mathrm{~h}$ following the final alcohol or saline conditioning session.

\section{TUNEL Assay}

Finally, to confirm that Daun02 was resulting in apoptosis of $\mathrm{NF}-\kappa \mathrm{B}$-activated cells, a TUNEL assay was used. Brains were extracted and fixed in $4 \%$ paraformaldehyde at $4{ }^{\circ} \mathrm{C}$ overnight. After washing with PBS three times, fixed brains were cryoprotected in $25 \%$ sucrose at $4{ }^{\circ} \mathrm{C}$ for 2 days and then frozen on dry ice. Fourteen micrometer sections were collected in a freezing cryostat. The apoptotic cells in situ were detected by the indirect TUNEL methods as described in the ApopTag Fluorescein In Situ Apoptosis Detection Kit (S7110, Millipore). All sections were counter stained with $1 \mu \mathrm{g} / \mathrm{ml}$ Hoechst at room temperature for $20 \mathrm{~min}$ to label nuclei. TUNEL-positive cells were quantified with ImageJ software.

\section{Statistics}

Statistical analyses were performed using Statistica software. Tests for main effects were performed using $t$-test (if two groups across one factor) or two-way ANOVA. When appropriate, post-hoc comparisons were performed using Newman-Keuls tests. For each experiment, data for males and females were compared and resulted in no statistical differences. Consequently, the data were combined.

\section{RESULTS}

\section{Alcohol CPP Increases NF- $\kappa$ B Activity in the NAC Shell and DR}

Mice were conditioned with $2.0 \mathrm{~g} / \mathrm{kg}$ ethanol $(n=19)$ and preference for the alcohol paired side was assessed
(Figure 1a). Control animals received saline on both sides of the CPP apparatus $(n=12)$. Two-way ANOVA revealed main effects of test session (pretest vs test; $\mathrm{F}(1,29)=7.2$, $p=0.01$ ) and treatment (saline vs alcohol; $\mathrm{F}(1,29)=7.9$, $p=0.009)$, as well as a test session $\times$ treatment interaction $(\mathrm{F}(1,29)=6.6, p=0.02)$. Mice conditioned with alcohol spent more time on the alcohol paired side when compared with their pretest, as well as when compared with saline conditioned animals on test day ( $p<0.01$ for all comparisons; Figure 1b).

In a parallel cohort of animals, mice ( $n=7 /$ group) were conditioned with $2.0 \mathrm{~g} / \mathrm{kg}$ ethanol or saline and killed $2 \mathrm{~h}$ following the final conditioning session (see Figure 1a). We chose this timepoint, because $\mathrm{NF}-\kappa \mathrm{B}$ has been shown to mediate learning and memory processes, and we hypothesized that this transcription factor would be involved in the formation of alcohol CPP. Tissue was stained for $\beta$-gal and several regions were analyzed including the NAC shell, NAC core, DR, insula, bed nucleus of the stria terminalis, basolateral amygdala, central amygdala, and lateral septum (Figures 1c-f and Supplementary Figure S3). When compared with animals conditioned with saline, animals receiving alcohol conditioning had significantly increased expression of $\beta$-gal in the NAC shell $(\mathrm{t}(9)=2.3, p=0.04$; Figures $1 \mathrm{c}$ and $\mathrm{d}$ ) and $\mathrm{DR}(\mathrm{t}(10)=3.9, p=0.003$; Figures $1 \mathrm{e}$ and $f$ ). There were no significant differences between saline and alcohol conditioned animals for any other region examined (see Supplementary Figure S3). There was also no difference between saline- and alcohol-treated animals when mice were returned to their homecage instead of being placed in the CPP chambers (see Supplementary Information), indicating that the activity seen is contingent upon exposure to the CPP apparatus.

Next, we further characterized NF- $\kappa \mathrm{B}$ activation via double-labeling immunohistochemistry (Figures $1 \mathrm{~g}$ and $\mathrm{h}$ ). Brain sections from the NAC shell and DR obtained from mice that underwent alcohol place conditioning were stained for $\beta$-gal and the neuronal marker NeuN ( $n=5-6 /$ region). Most $\beta$-gal expression colocalized with the neuronal marker NeuN, with $60 \%$ overlap in the NAC shell (Figure 1g) and $88 \%$ overlap in the DR (Figure 1h). In the NAC shell, neurons colocalized with $\beta$-gal accounted for $16 \%$ of the total neuronal population, indicating a relatively selective set of neurons expressing $\mathrm{NF}-\kappa \mathrm{B}$.

\section{Specific Lesioning of NF- $\kappa$ B-Expressing Cells in the NAC Shell Disrupts the Strength of Alcohol CPP}

Next, we aimed to selectively lesion NF- $\kappa \mathrm{B}$-expressing cells within the NAC shell and DR of NF- $\kappa$ B-LacZ reporter mice via Daun02 inactivation (see Figure 2 for schematic of Daun02 inactivation method). Animals received Daun02 or vehicle into the NAC shell or DR $2 \mathrm{~h}$ following each alcohol conditioning session. This time point was consistent with measurements of $\beta$-gal expression as shown in Figure 1. A delay of 3 days was included before assessing the change in preference to ensure the Daun02 had adequate time to lesion the cellular population of interest (Pfarr et al, 2015). The day following this initial test session, an additional test session was performed to examine retention of the place preference ('retest' session; Figure 3a).

When infused into the NAC shell following each alcoholconditioning session, Daun02 did not have an effect on 


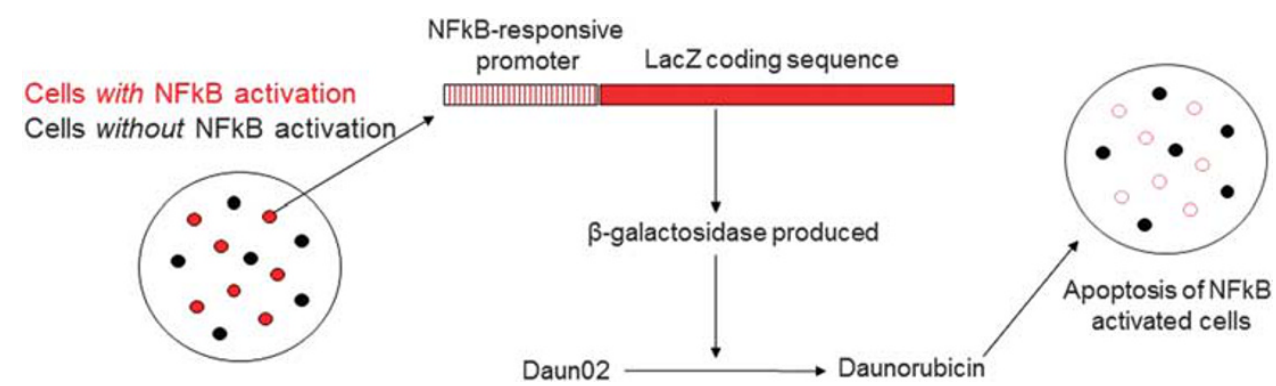

Figure 2 Schematic of Daun02 lesioning method. Daun02 is a prodrug that is converted to the active form (daunorubicin) by $\beta$-gal enzyme. This leads to apoptosis specifically in cells in which $\beta$-gal is expressed. In our transgenic reporter mice, this would be cells in which nuclear factor $\kappa$-light chain enhancer of activated $\mathrm{B}$ cells $(\mathrm{NF}-\mathrm{\kappa} \mathrm{B})$ is activated.

a

\begin{tabular}{|c|c|c|c|c|} 
Day 1 & Day 2-4 & Day 5-7 & Day 8 & Day 9 \\
\hline Pretest & $\begin{array}{c}\text { Conditioning }(2.0 \mathrm{~g} \mathrm{~kg} \mathrm{EtOH}) \\
\text { Recovery }\end{array}$ & Test & Retest \\
\hline $\begin{array}{l}\text { Daun 02 } \\
\text { infusion }\end{array}$ & $\begin{array}{l}\text { Daun02 } \\
\text { infusion }\end{array}$
\end{tabular}
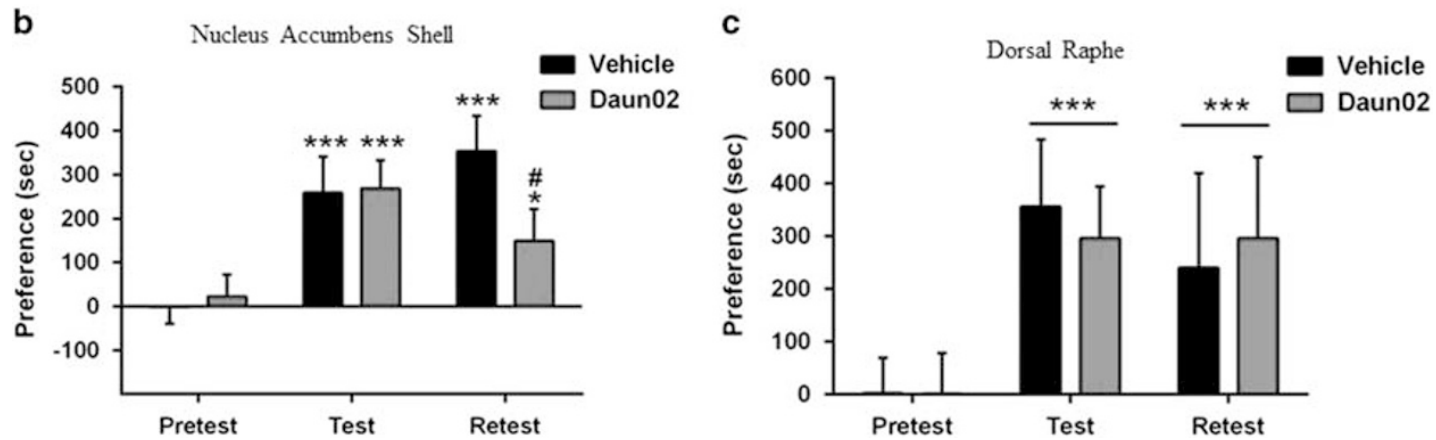

Figure 3 Daun02 weakens alcohol conditioned place preference (CPP) when infused into the nucleus accumbens (NAC) shell on conditioning days. (a) Timeline of experimental treatments and behavioral measurements. (b) Alcohol $(2 \mathrm{~g} / \mathrm{kg})$ induced a significant CPP. When Daun02 was infused into the NAC shell following each alcohol conditioning session there was no effect on test day preference, but retest preference was weakened. (c) There was no effect of Daun02 infusion in the dorsal raphe nucleus (DR). $* p<0.05$, $* * * p<0.001$ compared with pretest preference; $\# p=0.06$ compared with test day preference.

initial test day preference; however, preference towards the alcohol paired side during the retest session was reduced ( $n=14$ /group; Figure $3 \mathrm{~b}$ ). Two-way ANOVA revealed a main effect of test session $(\mathrm{F}(2,52=31.3, p<0.001)$ and a test session $\times$ treatment interaction $(\mathrm{F}(2,52)=6.3, p=0.004)$. Post-hoc tests indicated that there was a significant increase in preference for the alcohol-paired side on test day relative to pretest day for both treatment groups $(p<0.001)$. This increased preference persisted on retest day for both control mice ( $p<0.001$ for pretest $v s$ retest) and the Daun02 infused group $(p=0.02)$. There was a trend level decrease in preference score on retest day when compared to test day for the Daun02-treated group $(p=0.06)$, but not for the vehicle-treated group $(p=0.16)$. More permissive Fisher LSD tests indicated that retest preference was significantly lower in the Daun02 group compared to their test preference $(p=0.02)$ and also as compared with retest preference in vehicle-treated mice $(p=0.04)$. In the vehicle group, preference did not decrease between test and retest $(p=0.07)$. If anything, the preference was slightly increased in this group on the retest day.
No differences in test or retest preference were observed when Daun02 $(n=10)$ or vehicle $(n=8)$ was administered into the DR following conditioning sessions (Figure $3 \mathrm{c}$ ). Two-way ANOVA revealed only a main effect of test session $(\mathrm{F}(2,32)=12.5, p<0.001)$. Post-hoc tests across the factor of session indicated that preference was significantly higher on both test day $(p<0.001)$ and retest day $(p<0.001)$ when compared with pretest day. There was no difference between test and retest $(p=0.46)$.

Given the results of the experiments above, we focused on the NAC shell for the remainder of the study. Next, we assessed whether NF- $\kappa \mathrm{B}$ activity is induced during the initial test session and whether disruption of these cells is sufficient to impact retention of alcohol CPP. NF- $\kappa \mathrm{B}-L a c Z$ mice were conditioned with $2.0 \mathrm{~g} / \mathrm{kg}$ ethanol and assessed for place preference. Daun02 $(n=15)$ or vehicle $(n=13)$ was infused into the NAC shell $2 \mathrm{~h}$ following the test session (Figure $4 \mathrm{a}$ ). Daun02 did not significantly impact retest preference during the retest session three days later (Figure 4b). Two-way ANOVA detected only a main effect of test session ( $F$ $(2,54)=23.82, p<0.001)$. Post-hoc tests across the factor of 
a
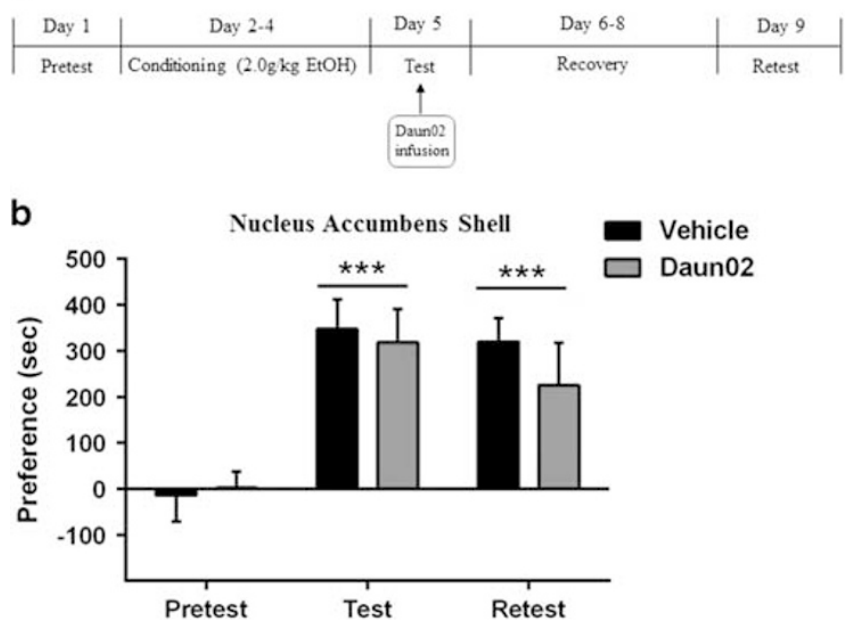

Figure 4 Daun02 does not affect retest preference when infused following the initial test day. (a) Timeline of experimental treatments and behavioral testing. (b) When Daun02 was infused into the nucleus accumbens (NAC) shell $2 \mathrm{~h}$ after the initial place preference test for conditioned place preference (CPP), there was no significant change in place preference observed on the retest day. $* * * * * 0.00$ I compared with pretest preference.

session indicated that preference was significantly higher on both test day $(p<0.001)$ and retest day $(p<0.001)$ as compared with pretest. There was no difference between test day and retest day $(p=0.23)$. Consistent with this, there was no difference in NF- $\kappa \mathrm{B}$ activated cells in the NAC shell $2 \mathrm{~h}$ after the test session when saline and alcohol conditioned animals were compared (see Supplementary Information). Together, these findings suggest that NF- $\kappa \mathrm{B}$ in the NAC shell is not activated on the CPP test day.

\section{Specific Lesioning of NF- $\kappa$ B-Expressing Cells in the NAC Shell Attenuates CPP to Moderate Dose of Alcohol}

The results above suggest that lesioning NF- $\kappa \mathrm{B}$-activated cells in the NAC shell during the development of alcohol CPP weakened the reward memory. However, this effect was only observed on the retest day and not the initial test day. We suspected that the CPP paradigm was not sensitive enough to pick up a decreased preference to this dose of alcohol on the test day, only when the mice were retested. To test this hypothesis, we conditioned mice with a lower dose of alcohol $(1.5 \mathrm{~g} / \mathrm{kg})$ and infused them with Daun02 $(n=7)$ or vehicle $(n=5)$ in the NAC shell on either conditioning days (Figure $5 \mathrm{a})$ or test day $(n=14$ Daun02 treated, $n=11$ vehicle treated; Figure 5b).

First, Daun02 or vehicle was infused into the NAC shell $2 \mathrm{~h}$ following each conditioning session with $1.5 \mathrm{~g} / \mathrm{kg}$ alcohol (Figure 5a). Three days later, animals underwent the test session. Animals receiving Daun02 displayed significantly attenuated preference towards the alcohol paired side on the test day compared to controls (Figure 5c). Two-way ANOVA revealed a main effect of test session $(F(1,10)=14.5$, $p=0.003)$ and a test session $\times$ treatment interaction ( $F$ $(1,10)=5.3, p=0.04)$, and a trend level main effect of treatment $(\mathrm{F}(1,10)=3.1, p=0.11)$. Post-hoc tests indicated that test day preference was increased relative to pretest for controls $(p=0.004)$ but not for Daun02 treated mice $(p=0.55)$. In addition, test day preference was significantly lower in the Daun02 group when compared with the control group $(p=0.02)$. Thus, selectively lesioning NF- $\kappa \mathrm{B}-$ expressing cells in the NAC shell during the conditioning phase impairs the development of alcohol CPP.

To assess the role of NF- $\kappa \mathrm{B}$ during the test session, animals were conditioned with $1.5 \mathrm{~g} / \mathrm{kg}$ alcohol and CPP was assessed the next day. Daun02 was infused into the NAC shell $2 \mathrm{~h}$ following the test session, and animals were allowed to recover for 3 days (Figure 5b). After the recovery period, animals were retested. No differences were observed between Daun02 and control groups (Figure 5d). Two-way ANOVA revealed only a main effect of test session $(F(2,23)=27.05$, $p<0.001)$. Post-hoc tests across the factor of test session indicated that preference for the alcohol paired side was higher than pretest preference on both test day $(p<0.001)$ and retest day $(p<0.001)$. There was no difference in preference between test day and retest day $(p=0.65)$. These results further corroborate that NF- $\kappa \mathrm{B}$ in the NAC shell has a temporally specific role on preference formation, as inactivation of $\mathrm{NF}-\kappa \mathrm{B}$-expressing cells during the conditioning phase, but not following the test session, attenuates alcohol CPP.

\section{Daun02 Inactivation Results in Apoptosis of NF- $\kappa$ B- Expressing Cells in the NAC Shell}

Finally, to confirm the findings of Pfarr et al (2015) that Daun02 induces apoptosis of $\beta$-gal expressing cells, and that this occurs in the NAC shell with our treatment schedule, mice were conditioned with $1.5 \mathrm{~g} / \mathrm{kg}$ ethanol and received Daun02 $(n=6)$ or vehicle $(n=4)$ into the NAC shell $2 \mathrm{~h}$ following each alcohol conditioning session. Mice were killed 3 days following the final conditioning session, the same time point at which preference was assessed above (Figure 5a). Tissue was collected and analyzed for apoptosis via TUNEL assay (Figures 5e and f). Daun02-treated animals displayed significantly more TUNEL-positive cells in the NAC shell compared with controls $(\mathrm{p}=0.026)$. This confirms that Daun02, when infused into the NAC shell of NF- $\kappa \mathrm{B}-\mathrm{LacZ}$ mice following alcohol place conditioning, results in apoptosis of NF- $\kappa \mathrm{B}$-expressing cells and removal from the functional circuitry of alcohol CPP.

\section{DISCUSSION}

The primary finding from these studies is that $\mathrm{NF}-\kappa \mathrm{B}$ activity, specifically in the NAC shell, mediates the development of alcohol CPP. NF $-\kappa \mathrm{B}$ activity was increased in this region $2 \mathrm{~h}$ following alcohol-conditioning sessions and specific lesioning of these cells attenuates the strength of alcohol CPP. When we used a high dose of alcohol, we did not detect blunted CPP on the initial test day, only on retest day when there was a longer delay between conditioning and testing. However, when we used a lower dose of alcohol, we saw effects on the initial test day, suggesting that this dose of alcohol was strong enough to induce CPP in controls, but was not so strong as to resist manipulation by disruption of $\mathrm{NF}-\kappa \mathrm{B}$-expressing cells. However, we did not see any effect when we selectively lesioned these cells following the test session at either dose. This suggests that NF- $\kappa \mathrm{B}$ is required for the development of alcohol CPP, but is not likely to be 
a

\begin{tabular}{|c|c|c|c|} 
Day 1 & Day 2-4 & Day 5-7 & Day 8 \\
\hline Pretest & $\begin{array}{c}\text { Conditioning }(1.5 \mathrm{~g} / \mathrm{kg} \mathrm{EtOH}) \\
\text { Daun02 } \\
\text { infusion }\end{array} \quad \begin{array}{l}\text { Daun02 } \\
\text { infusion }\end{array}$ & $\begin{array}{l}\text { Recovery } \\
\text { Daun02 } \\
\text { infusion }\end{array}$ &
\end{tabular}

b

\begin{tabular}{|c|c|c|c|c|} 
Day 1 & Day 2-4 & Day 5 & Day 6-8 & Day 9 \\
\hline Pretest & Conditioning (1.5g/kg EtOH) & Test & Recovery & Retest \\
& $\begin{array}{l}\text { Daun02 } \\
\text { infusion }\end{array}$
\end{tabular}

C

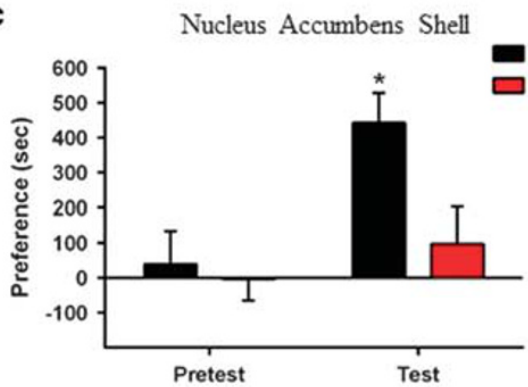

e

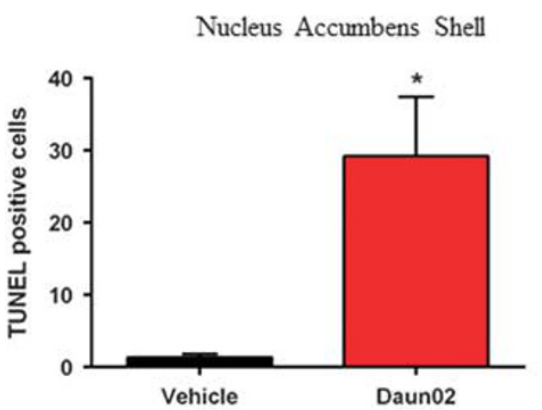

d

Vehicle Daun02

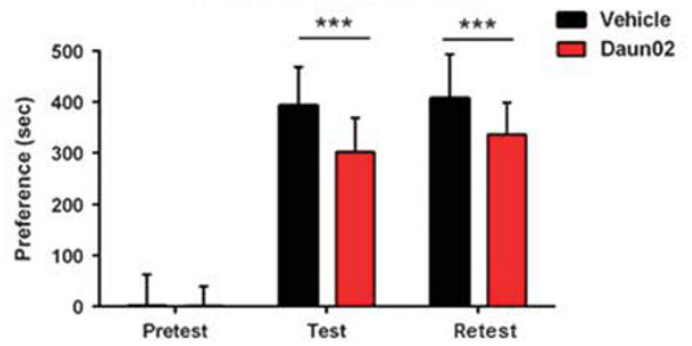

f
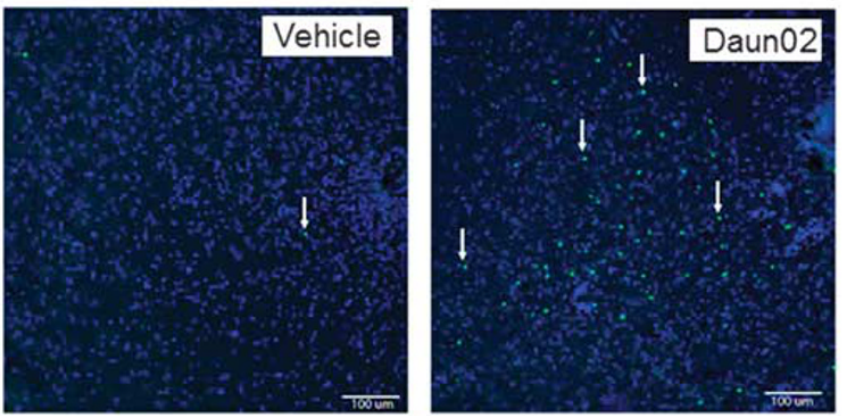

Figure 5 Daun02 infusion into the nucleus accumbens (NAC) shell during the conditioning phase attenuates the rewarding properties of a moderate dose of alcohol. (a, b) Timeline of experimental treatments and behavioral testing. (c) When infused into the NAC shell following each conditioning session with $1.5 \mathrm{~g} / \mathrm{kg}$ alcohol, Daun02 treatment attenuated alcohol place preference on the initial test day. $* p<0.05$ compared with all other groups. (d) When infused into the NAC shell following the initial test session, Daun02 treatment has no effect on alcohol place preference on the retest day. $* * * *<0.00$ I compared to pretest. (e, f) Graphical representation and representative images of Daun02-induced apoptosis in the NAC shell. White arrows indicate a representative TUNEL-positive cells. $* p<0.05$ compared with vehicle group. Scale bars, $100 \mu \mathrm{m}$.

reactivated during the expression of place preference, at least not in the NAC shell.

Previous research has demonstrated $\mathrm{NF}-\kappa \mathrm{B}$ activitation in response to very high doses of alcohol and suggests that NF$\kappa \mathrm{B}$ is a critical mediator of neurotoxicity that results from such challenges (Crews et al, 2006; Qin et al, 2008; Zou and Crews, 2010). In general, NF- $\kappa \mathrm{B}$ has a reputation for being associated with cellular stress and neurodegeneration. However, NF- $\kappa \mathrm{B}$ has many functions beyond these, including a role in learning and memory (Kaltschmidt et al, 2006; Snow et al, 2014), drug reward (Zhang et al, 2011) and spine remodeling in response to chronic drug exposure (Russo et al, 2009). Based on these functions of NF- $\kappa \mathrm{B}$, we suspected that this transcription factor may have a role in the rewarding properties of alcohol. Consistent with our hypothesis, we found that NF- $\kappa \mathrm{B}$ activity is in fact induced by moderate, rewarding doses of alcohol and NF- $\kappa \mathrm{B}-$ activated cells have a functional role in the development of alcohol CPP. To our knowledge, this is the first demonstration that $\mathrm{NF}-\kappa \mathrm{B}$ has a role in the positive, rewarding effects of alcohol. In addition, this is the first study to use the Daun02 inactivation method in $\mathrm{NF}-\kappa \mathrm{B}-L a c Z$ reporter mice.

Our results indicate regionally localized $\mathrm{NF}-\kappa \mathrm{B}$ activation during alcohol CPP. We analyzed several regions that are involved in reward processing and alcohol seeking, and only the NAC shell and DR showed significant $\mathrm{NF}-\kappa \mathrm{B}$ activation relative to saline treated controls. Furthermore, this activation specifically depended on alcohol exposure and introduction to the CPP chamber/procedure. We found that, under the conditions we used for testing, NF- $\kappa \mathrm{B}$ activity in the DR did not have a functional role in the development of alcohol CPP. However, we cannot rule out that the DR has some role in alcohol CPP, but was not revealed in the limited analysis performed.

It is intriguing that we observed such a strong activation of $\mathrm{NF}-\kappa \mathrm{B}$ in neurons. Based on the extensive role that NF- $\kappa \mathrm{B}$ 
has in neurological functions and behavioral processes (Christoffel et al, 2011, 2012; Koo et al, 2010; Russo et al, 2009), we would fully expect some level of activation in neurons, but it was unexpected that this would be the majority of the NF- $\kappa \mathrm{B}$-activated cells in the DR and NAC shell. This is, however, consistent with some recently published findings (Truitt et al, 2016). It is possible that the proportion cell types (neuronal $v s$ glial) where NF- $\kappa \mathrm{B}$ is activated by alcohol can be influenced by a complex set of variables including dose, exposure regimen, brain region, and homeostatic state of the animal.

Taken together, our experiments support a role of NF- $\kappa \mathrm{B}$ in alcohol CPP and localize this effect specifically to the NAC shell. This activation occurs primarily in neuronal cell types and selective disruption of NF- $\kappa \mathrm{B}$-expressing cells attenuates the development of alcohol CPP. We speculate that NF- $\kappa \mathrm{B}$ activation during place conditioning triggers specific gene expression that contributes to the formation of the reward memory. However, by the time of testing, these cellular alterations have taken place and NF- $\kappa \mathrm{B}$ is not reactivated. The specific genes that are targeted during alcohol CPP are unknown. NF- $\kappa \mathrm{B}$ has extremely diverse gene targets (Nennig and Schank, 2017) and a major focus of future research will be the identification of the genes that link NF- $\kappa \mathrm{B}$ activation by alcohol to the behavioral output of CPP.

\section{FUNDING AND DISCLOSURE}

This work was funded by NIH K99/R00 Pathway to Independence Award AA021805 (JRS), the University of Georgia Office for Vice President of Research (JRS), NINDS R01NS096176 (JFC), and NINDS R01NS097231 (JFC). The authors declare no conflict of interest.

\section{ACKNOWLEDGMENTS}

We thank Dr Scott Russo (Mt. Sinai Medical School) for providing NF- $\kappa \mathrm{B}-L a c Z$ breeder mice and Dr Georgia Hodes (Virginia Polytechnic Institute and State University) for breeding/genotyping advice. We thank Dr Nikolay Filipov (University of Georgia) for sharing his expertise in mouse cannulation surgery. We also thank Dr Yavin Shaham (National Institute on Drug Abuse) for thoughtful comments on our data.

\section{AUTHOR CONTRIBUTIONS}

SEN and JRS analyzed the data, prepared figures, and wrote the manuscript. SEN, JRS, CK, HDF, SHC, BMS, MKS, and JEE contributed to data collection. CL and JFC preformed the TUNEL assay. SEN, JRS, and MH contributed to the experimental design and drafting the manuscript.

\section{REFERENCES}

Bhakar AL, Tannis LL, Zeindler C, Russo MP, Jobin C, Park DS et al (2002). Constitutive nuclear factor-kappa B activity is required for central neuron survival. J Neurosci 22: 8466-8475.

Blednov YA, Benavidez JM, Geil C, Perra S, Morikawa H, Harris RA (2011). Activation of inflammatory signaling by lipopolysaccharide produces a prolonged increase of voluntary alcohol intake in mice. Brain Behav Immun 25(Suppl 1): S92-S105.

Boileau I, Assaad JM, Pihl RO, Benkelfat C, Leyton M, Diksic M et al (2003). Alcohol promotes dopamine release in the human nucleus accumbens. Synapse 49: 226-231.

Bossert JM, Stern AL, Theberge FR, Cifani C, Koya E, Hope BT et al (2011). Ventral medial prefrontal cortex neuronal ensembles mediate context-induced relapse to heroin. Nat Neurosci 14: 420-422.

Christoffel DJ, Golden SA, Dumitriu D, Robison AJ, Janssen WG, Ahn HF et al (2011). IkappaB kinase regulates social defeat stressinduced synaptic and behavioral plasticity. J Neurosci 31: 314-321.

Christoffel DJ, Golden SA, Heshmati M, Graham A, Birnbaum S, Neve RL et al (2012). Effects of inhibitor of kappaB kinase activity in the nucleus accumbens on emotional behavior. Neuropsychopharmacology 37: 2615-2623.

Crews F, Nixon K, Kim D, Joseph J, Shukitt-Hale B, Qin L et al (2006). BHT blocks NF-kappaB activation and ethanol-induced brain damage. Alcohol Clin Exp Res 30: 1938-1949.

Crews FT, Nixon K (2009). Mechanisms of neurodegeneration and regeneration in alcoholism. Alcohol Alcohol 44: 115-127.

Crews FT, Sarkar DK, Qin L, Zou J, Boyadjieva N, Vetreno RP (2015). Neuroimmune function and the consequences of alcohol exposure. Alcohol Res 37: 344-351.

Cruz FC, Babin KR, Leao RM, Goldart EM, Bossert JM, Shaham Y et al (2014). Role of nucleus accumbens shell neuronal ensembles in context-induced reinstatement of cocaine-seeking. J Neurosci 34: 7437-7446.

Cruz FC, Koya E, Guez-Barber DH, Bossert JM, Lupica CR, Shaham $Y$ et al (2013). New technologies for examining the role of neuronal ensembles in drug addiction and fear. Nat Rev Neurosci 14: 743-754.

de Guglielmo G, Crawford E, Kim S, Vendruscolo LF, Hope BT, Brennan $M$ et al (2016). Recruitment of a neuronal ensemble in the central nucleus of the amygdala is required for alcohol dependence. J Neurosci 36: 9446-9453.

Fanous S, Goldart EM, Theberge FR, Bossert JM, Shaham Y, Hope BT (2012). Role of orbitofrontal cortex neuronal ensembles in the expression of incubation of heroin craving. J Neurosci 32: 11600-11609.

Farquhar D, Pan BF, Sakurai M, Ghosh A, Mullen CA, Nelson JA (2002). Suicide gene therapy using E. coli beta-galactosidase. Cancer Chemother Pharmacol 50: 65-70.

Funk D, Coen K, Tamadon S, Hope BT, Shaham Y, Le AD (2016). Role of central amygdala neuronal ensembles in incubation of nicotine craving. J Neurosci 36: 8612-8623.

Gerondakis S, Fulford TS, Messina NL, Grumont RJ (2014). NF-kappaB control of $\mathrm{T}$ cell development. Nat Immunol 15: 15-25.

Kaltschmidt B, Ndiaye D, Korte M, Pothion S, Arbibe L, Prullage M et al (2006). NF-kappaB regulates spatial memory formation and synaptic plasticity through protein kinase A/CREB signaling. Mol Cell Biol 26: 2936-2946.

Koo JW, Russo SJ, Ferguson D, Nestler EJ, Duman RS (2010). Nuclear factor-kappaB is a critical mediator of stress-impaired neurogenesis and depressive behavior. Proc Natl Acad Sci USA 107: 2669-2674.

Koya E, Golden SA, Harvey BK, Guez-Barber DH, Berkow A, Simmons DE et al (2009). Targeted disruption of cocaineactivated nucleus accumbens neurons prevents context-specific sensitization. Nat Neurosci 12: 1069-1073.

Nennig SE, Schank JR (2017). The role of $\mathrm{NF}_{\kappa} \mathrm{B}$ in drug addiction: beyond inflammation. Alcohol Alcohol 52: 172-179.

Oeckinghaus A, Ghosh S (2009). The NF-kappaB family of transcription factors and its regulation. Cold Spring Harb Perspect Biol 1: a000034. 
Pfarr S, Meinhardt MW, Klee ML, Hansson AC, Vengeliene V, Schonig K et al (2015). Losing control: excessive alcohol seeking after selective inactivation of cue-responsive neurons in the infralimbic cortex. J Neurosci 35: 10750-10761.

Qin L, Crews FT (2012). NADPH oxidase and reactive oxygen species contribute to alcohol-induced microglial activation and neurodegeneration. J Neuroinflam 9: 5.

Qin L, He J, Hanes RN, Pluzarev O, Hong JS, Crews FT (2008). Increased systemic and brain cytokine production and neuroinflammation by endotoxin following ethanol treatment. J Neuroinflam 5: 10 .

Qin L, Wu X, Block ML, Liu Y, Breese GR, Hong JS et al (2007). Systemic LPS causes chronic neuroinflammation and progressive neurodegeneration. Glia 55: 453-462.

Russo SJ, Wilkinson MB, Mazei-Robison MS, Dietz DM, Maze I, Krishnan V et al (2009). Nuclear factor kappa B signaling regulates neuronal morphology and cocaine reward. J Neurosci 29: 3529-3537.

Salgado S, Kaplitt MG (2015). The nucleus accumbens: a comprehensive review. Stereotact Funct Neurosurg 93: 75-93.

Snow WM, Stoesz BM, Kelly DM, Albensi BC (2014). Roles for NFkappaB and gene targets of NF-kappaB in synaptic plasticity, memory, and navigation. Mol Neurobiol 49: 757-770.
Truitt JM, Blednov YA, Benavidez JM, Black M, Ponomareva O, Law J et al (2016). Inhibition of IKKbeta reduces ethanol consumption in C57BL/6J Mice. eNeuro 3.

Wang X, Douglas SD, Commons KG, Pleasure DE, Lai J, Ho $C$ et al (2004). A non-peptide substance $\mathrm{P}$ antagonist (CP-96,345) inhibits morphine-induced NF-kappa B promoter activation in human NT2-N neurons. $J$ Neurosci Res 75: $544-553$.

Zhang X, Cui Y, Jing J, Cui Y, Xin W, Liu X (2011). Involvement of p38/NF-kappaB signaling pathway in the nucleus accumbens in the rewarding effects of morphine in rats. Behav Brain Res 218: 184-189.

Zou J, Crews F (2006). CREB and NF-kappaB transcription factors regulate sensitivity to excitotoxic and oxidative stress induced neuronal cell death. Cell Mol Neurobiol 26: 385-405.

Zou J, Crews F (2010). Induction of innate immune gene expression cascades in brain slice cultures by ethanol: key role of NF-kappaB and proinflammatory cytokines. Alcohol Clin Exp Res 34: 777-789.

Zou JY, Crews FT (2005). TNF alpha potentiates glutamate neurotoxicity by inhibiting glutamate uptake in organotypic brain slice cultures: neuroprotection by NF kappa B inhibition. Brain Res 1034: 11-24.

Supplementary Information accompanies the paper on the Neuropsychopharmacology website (http://www.nature.com/npp) 